\title{
PENGARUH SIMPANAN POKOK DAN SIMPANAN WAJIB TERHADAP SISA HASIL USAHA PADA KOPERASI SAWIT USAHA MANUNGGAL INDRAGIRI HULU
}

\author{
Oleh: \\ HASANAH YASPITA \\ Sekolah Tinggi Ilmu Ekonomi Indragiri (STIE-I) Rengat \\ Email: hasanahyaspita@stieindragiri.ac.id
}

\begin{abstract}
This research is at the Manunggal Oil Palm Cooperative, Indragiri Hulu which lasted approximately 4 months. This study aims to find out and analyzed the principal savings and savings must affect the remaining results of operations at the Manunggal Oil Palm Cooperative in Indragiri Hulu. This research used quantitative method. To analyzed the data, writers used SPSS Version 21 program. The data analysis stages used are classic assumption tests, namely normality test, autocorrelation test and multicollinearity test. Multiple linear regression analysis, namely correlation coefficient analysis, determination coefficient $(R 2)$ and hypothesis testing results, simultaneous significance test ( $F$ statistical test), $t$ test ( $t$-test). The results of this study obtained an equation that is $Y=1030.54+1779.89 X 1+0.31 X 2$. That is, if the principal Savings coefficient value (X1) and the obligatory Savings Coefficient (X2) is equal to 0 then the value of the remaining operating results (Y) variable is equal to 1030.54 points. If the basic deposit coefficient (X1) increases / increases 1 unit while the other independent variables remain, then the remaining operating results $(Y)$ will increase by 1779.89 points and if the coefficient value of the required deposit (X2) increases / increases 1 unit while other independent variables remain, then the remaining operating results $(Y)$ will increase by 0.31 points. From the results of testing the hypothesis, it can be seen that $F$ count $<F$ table is $0.801<19.00$. So that the two independent variables namely the principal Savings and the required Savings together together do not significantly influence the dependent variable, namely the residual proceeds of the business at the Manunggal Oil Palm Cooperative in Indragiri Hulu. The result of multiple correlation coefficient $(R)$ is 0.667 . This shows the level of relationship between all independent variables on the dependent variable in this study in the criteria of closeness of the medium relationship or moderate influence. $R$ Squarea value $(R 2)$ is 0.445 means the remaining variable results of the business can be explained by the principal savings and mandatory savings variables of $44.5 \%$, while the remaining $55.5 \%$ is explained by other independent variables that was not examined in this research.
\end{abstract}

Keywords: principal savings, mandatory savings, surplus

\begin{abstract}
Abstrak
Penelitian ini dilakukan di Koperasi Sawit Usaha Manunggal Indragiri Hulu yang berlangsung lebih kurang 4 bulan. Penelitian ini bertujuan untuk mengetahui dan menganalisis simpanan pokok dan simpanan wajib berpengaruh terhadap sisa hasil usaha pada Koperasi Sawit Usaha Manunggal Indragiri Hulu. Metode pendekatan yang digunakan dalam penelitian ini adalah metode kuantitatif. Dengan Analisis data untuk diolah dengan program SPSS Version 21. Adapun tahap-tahap analisis data yang digunakan adalah uji asumsi klasik yaitu uji normalitas, uji autokorelasi dan uji multikolonieritas. Analisis regresi linier berganda yaitu analisis koefisien korelasi, koefisien determinasi $\left(R^{2}\right)$ dan hasil pengujian hipotesis, uji signifikansi simultan (uji statistik $F$ ), Uji $t$ (t-test). Hasil penelitian ini diperoleh persamaan yaitu $Y=1030,54+1779,89 X_{1}+0,31 X_{2}$. Artinya, jika nilai koefisien Simpanan pokok $\left(X_{1}\right)$ dan Koefisien Simpanan wajib $\left(\mathrm{X}_{2}\right)$ sama dengan 0 maka nilai variabel Sisa hasil usaha $(Y)$ adalah sebesar 1030,54 poin. Jika nilai koefisien Simpanan pokok $\left(X_{1}\right)$ mengalami kenaikan/peningkatan 1 satuan sedangkan variabel independent lainnya tetap, maka Sisa hasil usaha $(Y)$ akan meningkat sebesar 1779,89 poin dan jika nilai koefisien Simpanan wajib $\left(X_{2}\right)$ mengalami kenaikan/peningkatan 1 satuan sedangkan variabel independent lainnya tetap, maka sisa hasil usaha (Y) akan meningkat sebesar 0,31 poin. Dari hasil pengujian hipotesis, dapat diketahui bahwa $F$ hitung $<F$ tabel yaitu 0,801 < 19,00. Sehingga kedua variabel bebas yaitu Simpanan pokok dan Simpanan wajib secara bersama-sama bersama-sama tidak berpengaruh secara signifikan terhadap variabel terikat yaitu sisa hasil usaha pada Koperasi Sawit Usaha Manunggal Indragiri Hulu. Hasil koefisien korelasi berganda (R) yaitu 0,667 .Hal ini menunjukkan tingkat hubungan antara seluruh variabel independent terhadap variabel dependent dalam penelitian ini berada dalam kriteria keeratan hubungan sedang atau pengaruh sedang. Nilai $R$ Squarea $\left(R^{2}\right)$ adalah 0,445 artinya variabel sisa hasil usaha dapat dijelaskan oleh variabel simpanan pokok dan simpanan wajib sebesar 44,5\%, sedangkan sisanya sebesar 55,5\% dijelaskan oleh variabel-variabel bebas lainnya yang tidak diteliti.
\end{abstract}

Kata Kunci : (Simpanan pokok, Simpanan wajib, Sisa hasil usaha) 


\section{PENDAHULUAN}

Koperasi memiliki karakter khas yang berbeda dengan badan usaha yang lain, yaitu memiliki identitas ganda, yang para anggota koperasi disamping sebagai pemilik juga sebagai pelanggan atau pengguna dari produk atau jasa yang dihasilkan koperasi itu. Menurut UU No. 25 Tahun 1992 tentang perkoperasian BAB 1 Pasal 1 Koperasi adalah "Badan usaha yang beranggotakan orang seorang atau badan hukum koperasi dengan melandaskan kegiatannya berdasarkan prinsip koperasi sekaligus sebagai gerakan ekonomi rakyat yang berdasarkan atas azas kekeluargaan". Koperasi tidak mengenal istilah "keuntungan", dikarenakan kegiatan usaha didalam koperasi bukan sematamata mencari keuntungan tetapi berorientasi pada manfaat.

Untuk menumbuhkan koperasi supaya berkembang, maka dibutuhkan ada keuntungan atau yang disebut dengan sisa hasil usaha (SHU). Menurut UU No. 25 Tahun 1992 Pasal 45, Sisa Hasil Usaha Koperasi adalah Pendapatan koperasi yang diperoleh dalam satu tahun buku dikurangi dengan biaya penyusutan dan kewajiban lainnya termasuk pajak dalam satu tahun buku yang bersangkutan.

Salah satu koperasi yang terdapat di Kabupaten Indragiri Hulu adalah Koperasi Sawit Usaha Manunggal. Koperasi Sawit Usaha Manunggal ini terdapat di Desa Seresam Kecamatan Seberida. Koperasi Sawit Usaha Manunggal memiliki Simpanan Pokok, Simpanan Wajib dan SHU yang cukup besar dimana akan di tampilkan pada tabel dibawah ini :

\section{Tabel 1}

Simpanan Pokok, Simpanan Wajib dan SHU Koperasi Sawit Usaha Manunggal

\begin{tabular}{|c|c|c|c|}
\hline Tahun & Simpanan Pokok & Simpanan Wajib & SHU \\
\hline 2014 & 5.650 .000 & 1.114 .314 .000 & 657.242 .251 \\
\hline 2015 & 5.720 .000 & 1.363 .814 .000 & 429.457 .620 \\
\hline 2016 & 5.880 .000 & 1.622 .588 .000 & 232.956 .259 \\
\hline 2017 & 5.930 .000 & 1.888 .975 .000 & 392.184 .432 \\
\hline 2018 & 5.940 .000 & 2.157 .105 .000 & 540.748 .425 \\
\hline
\end{tabular}

Sumber : Koperasi Sawit Usaha Manunggal

Di Koperasi Sawit Usaha Manunggal dengan meningkatnya simpanan pokok dan simpanan wajib tidak sejalan dengan peningkatan SHU koperasi setiap tahunnya. Berkaitan dengan uraian di atas maka penulis bermaksud membahas dan memberikan judul "PENGARUH SIMPANAN POKOK DAN SIMPANAN WAJIB TERHADAP SISA HASIL USAHA PADA KOPERASI SA WIT USAHA MANUNGGAL INDRAGIRI HULU"

\section{TINJAUAN PUSTAKA DAN HIPOTESIS}

\section{A. Koperasi}

Koperasi mengandung makna "kerja sama". Koperasi (cooperative) bersumber dari kata co-operation yang artinya "kerja sama". Koperasi berkenaan dengan manusia sebagai individu dan dengan kehidupannya dalam masyarakat. Manusia tidak dapat melakukan kerja sama sebagai satu unit, dia memerlukan orang lain dalam suatu kerangka kerja sosial (Sitio dan Tamba, 2001).

\section{B. Sisa Hasil Usaha}

Berdasarkan UU No. 25 Tahun 1992 tentang koperasi pasal 45 ayat 2 bahwa, sisa hasil usaha setelah dikurangi dana cadangan, dibagikan kepada anggota sebanding dengan jasa usaha yang dilakukan oleh masing-masing anggota dengan koperasi, serta digunakan untuk keperluan pendidikan perkoperasian dan keperluan lain dari koperasi, sesuai dengan keputusan rapat anggota. Pada rapat anggota tahunan, sisa hasil usaha diputuskan untuk dibagi sesuai dengan ketentuan yang tercantum dalam Anggaran Dasar Koperasi. 
Indikator yang digunakan adalah SHU rata-rata anggota atas jasa modal dan SHU atas jasa usaha yang dihitung dengan satuan rupiah. (Sitio, 2001:87).

\section{Simpanan Anggota}

Simpanan anggota didalam koperasi simpan pinjam sangat penting karena merupakan salah satu modal sendiri bagi koperasi tersebut. Didalam koperasi, permodalan koperasi menurut Undang-Undang Republik Indonesia No.25 Tahun 1992 tentang perkoperasian Indonesia pasal ayat dan bahwa modal koperasi terdiri dari modal sendiri dan modal pinjaman.

Faktor-faktor yang Mempengaruhi Simpanan Anggota

Keaktifan anggota menabung

Bertambahnya jumlah anggota baru

\section{Kerangka Pemikiran}

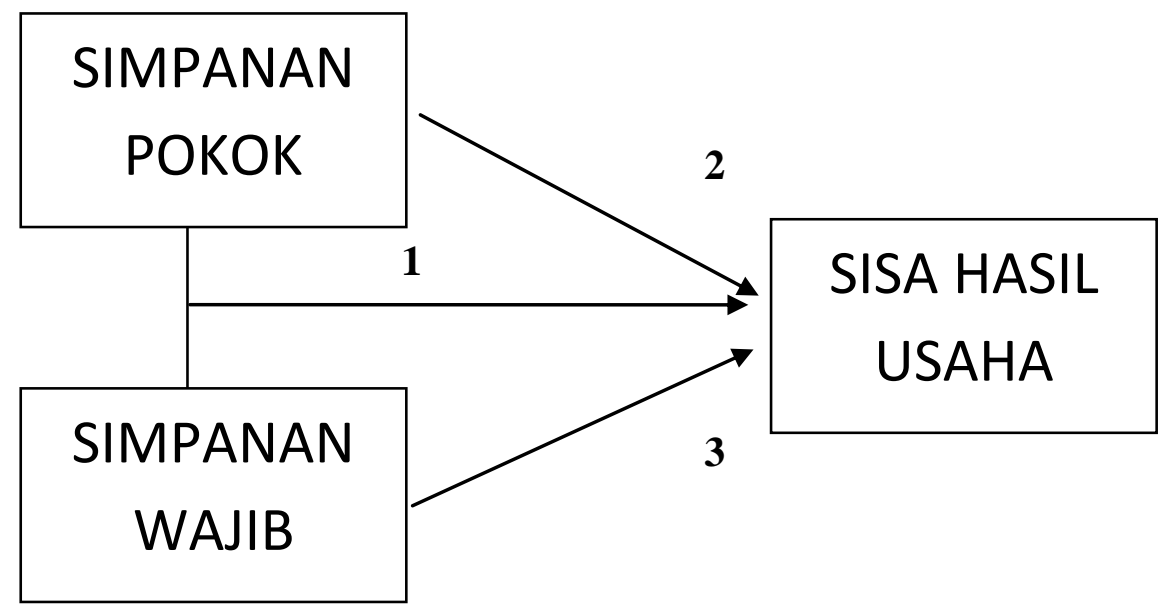

Variabel Independent/Bebas

Variabel Dependent/Terikat

Gambar 1 : Kerangka Pemikiran

Sumber : Dikembangkan Peneliti dalam Penelitian ini

\section{Hipotesis Penelitian}

1. Diduga simpanan pokok dan simpanan wajib secara simultan berpengaruh signifikan terhadap sisa hasil usaha pada Koperasi Sawit Usaha Manunggal Indragiri Hulu.

2. Diduga simpanan pokok secara parsial berpengaruh signifikan terhadap sisa hasil usaha pada Koperasi Sawit Usaha Manunggal Indragiri Hulu.

3. Diduga simpanan wajib secara parsial berpengaruh signifikan terhadap sisa hasil usaha pada Koperasi Sawit Usaha Manunggal Indragiri Hulu.

\section{METODE PENELITIAN}

\section{A. Lokasi dan Waktu Penelitian} bulan.

Koperasi Sawit Usaha Manunggal Indragiri Hulu.Penelitian ini berlangsung lebih kurang 4

B. Jenis dan Sumber Data

Jenis Kuantitatif dan Sumber Data Sekunder.

\section{Metode Pengumpulan Data}

a. Studi Perpustakaan

b. Dokumentasi 


\section{Analisis Data}

Metode pendekatan yang digunakan dalam penelitian ini adalah metode kuantitatif. Analisis data untuk diolah dengan program SPSS Version 21. Adapun tahap-tahap analisis data yang digunakan adalah sebagai berikut :

1. Uji Asumsi Klasik
a. Uji Normalitas
b. Uji Autokorelasi
c. Uji Multikolonieritas

2. Analisis Regresi Linier Berganda

Persamaan regresi linier berganda adalah sebgai berikut (Ghozali, 2009:89)

$$
\mathbf{Y}=\alpha+\boldsymbol{\beta}_{1} \mathbf{X}_{1}+\boldsymbol{\beta}_{2} \mathbf{X}_{2}
$$

a. Analisis Koefisien Korelasi

Tujuan metode ini adalah analisis yang digunakan untuk membahas kuatnya hubungan antara variabel-variabel yang diteliti angka yang menunjukkan hubungan antara variabel-variabel diberi notasi " $r$ "

b. Koefisien Determinasi $\left(\mathrm{R}^{2}\right)$

$\mathrm{R}$ Square $(\mathrm{R})$ atau Koefesien Determinasi $(\mathrm{KD})=(\mathrm{r})^{2} \times 100 \%$

3. Hasil Pengujian Hipotesis

a. Uji Signifikansi Simultan (Uji Statistik F)

b. Uji t (t-test)

\section{HASIL DAN PEMBAHASAN}

1. Hasil Penelitian

1). Uji Asumsi Klasik

a. Uji Normalitas

One-Sample Kolmogorov-Smirnov Test

\begin{tabular}{|c|c|c|}
\hline & & $\begin{array}{c}\text { Unstandardized } \\
\text { Residual }\end{array}$ \\
\hline $\mathrm{N}$ & & \\
\hline Normal Parameters ${ }^{a, b}$ & $\begin{array}{l}\text { Mean } \\
\text { Std. Deviation } \\
\text { Absolute }\end{array}$ & $\begin{array}{r}.0000000 \\
11.89851652 \\
.130\end{array}$ \\
\hline Most Extreme Differences & Positive & $\begin{array}{r}.130 \\
-120\end{array}$ \\
\hline Kolmogorov-Smirnov Z & & .291 \\
\hline Asymp. Sig. (2-tailed) & & 1.000 \\
\hline
\end{tabular}

a. Test distribution is Normal.

b. Calculated from data.

Sumber : Data OlahanSPSS

Dari tabel diatas dilihat tingkat sig adalah 1.0 nilainya lebih besar dari tingkat signifikan yang digunakan pada penelitian ini $(\alpha=0,05)$. Dengan demikian dapat disimpulkan bahwa semua variabel tersebut berdistribusi normal.

b. Uji Autokorelasi

\begin{tabular}{|l|r|}
\hline & $\begin{array}{r}\text { Unstandardized } \\
\text { Residual }\end{array}$ \\
\hline Test Value $^{\mathrm{a}}$ & .37420 \\
Cases $<$ Test Value & 2 \\
Cases $>=$ Test Value & 3 \\
Total Cases & 5 \\
Number of Runs & 3 \\
Z & .000 \\
Asymp. Sig. (2-tailed) & 1.000 \\
\hline
\end{tabular}


Dari tabel diatas didapat Asymp. Sig. (2-tailed) sebesar 1,0 lebih besar dari 0,05. Maka tidak terjadi masalah Autokorelasi.

c. Uji Multikolinieritas

\begin{tabular}{|rl|r|r|}
\hline \multicolumn{2}{|l|}{ Model } & \multicolumn{2}{|c|}{ Collinearity Statistics } \\
\cline { 3 - 4 } & \multicolumn{1}{|c|}{ Tolerance } & \multicolumn{1}{c|}{ VIF } \\
\hline \multirow{3}{*}{1} & (Constant) & & \\
& SimpananPokok & .255 & 3.919 \\
& SimpananWajib & .255 & 3.919 \\
\hline
\end{tabular}

a. Dependent Variable: SHU

Dapat diketahui nilai VIF sebesar 3,919< 10 dengan nilai tolerance sebesar 0,255>0,10. Sehingga dapat disimpulkan bahwa model regresi dalam penelitian ini tidak terjadi gejala korelasi antar variabel.

2). Analisis Regresi Linear Berganda

\begin{tabular}{|rl|r|r|r|r|r|}
\hline \multicolumn{2}{|l|}{ Model } & \multicolumn{2}{|c|}{ Unstandardized Coefficients } & \multicolumn{1}{c|}{$\begin{array}{c}\text { Standardized } \\
\text { Coefficients }\end{array}$} & \multicolumn{1}{c|}{ Sig. } \\
\cline { 3 - 6 } & \multicolumn{1}{|c|}{ B } & Std. Error & \multicolumn{1}{c|}{ Beta } & & \\
\hline \multirow{2}{*}{1} & (Constant) & 1030.537 & 828.867 & & 1.243 & .340 \\
& SimpananPokok & 1779.889 & 1520.444 & 1.221 & 1.171 & .362 \\
& SimpananWajib & .309 & .403 & .800 & .767 & .523 \\
\hline
\end{tabular}

a. Dependent Variable: SHU

Sehingga hubungan yang terjadi dapat ditulis dalam bentuk persamaan (model) regresi yaitu:

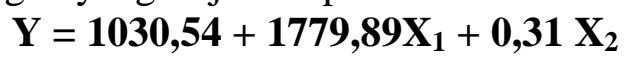

Adapun interpretasi dari model regresi dimuka adalah:

1. Nilai konstanta $(\mathrm{a}=1030,54)$ merupakan konstanta apabila semua nilai variabel bebas $=0$, maka nilai variabel terikat (Y) sebesar 1030,54 poin.

2. Nilai koefisien Simpanan Pokok $(X 1=1779,89)$. Artinya jika variabel indenpendent lainnya tetap dan Simpanan Pokok (X1) mengalami/peningkatan satu satuan, maka Sisa hasil usaha meningkat sebesar 1779,89 poin. Koefisien bernilai positif artinya terjadi hubungan yang positif antara Simpanan Pokok dengan Sisa hasil usaha. Semakin bagus Simpanan pokok maka akan meningkatkan Sisa hasil usaha.

3. Nilai koefisien Simpanan wajib $(\mathrm{X} 2=0.31)$. Artinya jika variabel indenpendent lainnya tetap dan Simpanan Wajib (X2) mengalami/peningkatan satu satuan, maka sisa hasil usaha akan meningkat sebesar0,31 poin. Koefisien bernilai positif artinya terjadi hubungan yang positif antara Simpanan wajib dengan Sisa hasil usaha. Semakin tinggi Simpanan wajib maka akanmeningkatkan Sisa hasil usaha.

\section{a. Analisis Koefisien Korelasi Berganda (R)}

\begin{tabular}{|l|r|r|c|c|}
\hline Model & $\mathrm{R}$ & $\mathrm{R}$ Square & $\begin{array}{c}\text { Adjusted R } \\
\text { Square }\end{array}$ & $\begin{array}{c}\text { Std. Error of the } \\
\text { Estimate }\end{array}$ \\
\hline 1 & $.667^{\mathrm{a}}$ & .445 & \multicolumn{3}{|c|}{.110} & 16.82704 \\
\hline a. & Predictors: (Constant), SimpananWajib, SimpananPokok
\end{tabular}

Berdasarkan tabel diatas, dapat diketahui hasil koefisien korelasi berganda (R) yaitu 0,667. Hal ini menunjukkan tingkat hubungan antara seluruh variabel independent terhadap variabel dependent dalam penelitian ini berada dalam kriteria keeratan hubungan sedang atau pengaruh sedang. Berikut tabel standar kategori derajat hubungan. 


\section{b. Koefisien Determinasi}

Model Summary

\begin{tabular}{|l|r|r|r|c|}
\hline Model & $\mathrm{R}$ & $\mathrm{R}$ Square & $\begin{array}{c}\text { Adjusted R } \\
\text { Square }\end{array}$ & $\begin{array}{c}\text { Std. Error of the } \\
\text { Estimate }\end{array}$ \\
\hline 1 & $.667^{\mathrm{a}}$ & .445 & .110 & 16.82704 \\
\hline
\end{tabular}

a. Predictors: (Constant), SimpananWajib, SimpananPokok

Sumber : Data Olahan.

Berdasarkan tabel 10 di atas juga dapat terlihat koefisien determinasi $\left(\mathrm{R}^{2}\right)$.Dari tabel model summary tersebut dapat diketahui nilai $\mathrm{R}$ Squarea $\left(\mathrm{R}^{2}\right)$ yang terlihat dari tabel 10 adalah 0,445 artinya variabel sisa hasil usaha dapat dijelaskan oleh variabel simpanan pokok dan simpanan wajib sebesar $44,5 \%$, sedangkan sisanya sebesar $55,5 \%$ dijelaskan oleh variabel-variabel bebas lainnya yang tidak diteliti.

\section{Hasil Pengujian Hipotesis}

a. Uji F (Uji Hipotesis Secara Simultan)

Hasil perhitungan F hitung dengan program IBM SPSS Versi 21.0 dan perbandingan dengan F tabel adalah sebagai berikut.

Tabel 11 : Hasil Uji Simultan

\begin{tabular}{|rl|r|r|r|r|r|}
\hline Model & & Sum of Squares & \multicolumn{1}{|c|}{ df } & Mean Square & F & Sig. \\
\hline \multirow{2}{*}{1} & Regression & 453.772 & 2 & 226.886 & .801 & $.555^{\text {D }}$ \\
& Residual & 566.299 & 2 & 283.149 & & \\
& Total & 1020.071 & 4 & & & \\
\hline
\end{tabular}

a. Dependent Variable: SHU

b. Predictors: (Constant), SimpananWajib, SimpananPokok

Sumber : Data Olahan.

Dari tabel hasil perhitungan di atas, dapat diketahui bahwa $\mathrm{F}$ hitung sebesar 0,801 dan $\mathrm{F}$ tabel dengan taraf signifikan $5 \%$.

$$
\begin{aligned}
\text { F tabel } & =(\mathrm{k}) ;(\mathrm{n}-\mathrm{k}-1) \\
& =(2) ;(5-2-1) \\
& =2 ; 2 \\
& =19,00
\end{aligned}
$$

Dari hasil perhitungan $\mathrm{F}$ tabel diatas, dapat diketahui bahwa $\mathrm{F}$ hitung $<\mathrm{F}$ tabel yaitu $0,801<$ 19,00. Sehingga kedua variabel bebas yaitu Simpanan pokok dan Simpanan wajib secara bersamasama bersama-sama tidak berpengaruh secara signifikan terhadap variabel terikatyaitu sisa hasil usaha pada Koperasi Sawit Usaha Manunggal Indragiri Hulu.

\begin{tabular}{|c|c|c|c|c|c|c|}
\hline \multirow[t]{2}{*}{ Mode } & & \multicolumn{2}{|c|}{ Unstandardized Coefficients } & \multirow{2}{*}{$\begin{array}{c}\text { Standardized } \\
\text { Coefficients } \\
\text { Beta }\end{array}$} & \multirow[t]{2}{*}{$\mathrm{t}$} & \multirow[t]{2}{*}{ Sig. } \\
\hline & & $\mathrm{B}$ & Std. Error & & & \\
\hline \multirow{3}{*}{1} & (Constant) & 1030.537 & 828.867 & & 1.243 & .340 \\
\hline & $\begin{array}{l}\text { SimpananP } \\
\text { okok }\end{array}$ & 1779.889 & 1520.444 & 1.221 & 1.171 & .362 \\
\hline & $\begin{array}{l}\text { Simpanan } \\
\text { Wajib }\end{array}$ & .309 & .403 & .800 & .767 & .523 \\
\hline
\end{tabular}

\section{b. Uji Parsial (Uji t)}

Tabel 12: Hasil Uji Parsial

Coefficients $^{a}$

a. Dependent Variable: SHU

Sumber : Data Olahan 
Dari tabel di atas, dapat dilihat nilai t hitung dari masing-masing variabel bebas, yaitu Simpanan pokok dan Simpanan wajib. Selain itu, $t$ tabel dapat diketahui dengan perhitungan berikut.

$$
\begin{aligned}
\mathrm{t} \text { tabel } & =\alpha / 2, \mathrm{n}-\mathrm{k} \\
& =0,05 / 2 ; 5-2 \\
& =0,025 ; 3 \\
& =3,18245
\end{aligned}
$$

Hasil pengujian masing-masing variabel adalah sebagai berikut :

1. Variabel X1 (Simpanan pokok) yaitu $1,171<3,18245$. Sehingga dapat disimpulkan bahwa variabel Simpanan pokok secara parsial tidak berpengaruh signifikan terhadap sisa hasil usaha pada Koperasi Sawit Usaha Manunggal Indragiri Hulu.

2. Variabel X2 (Simpanan wajib) yaitu $0,767<3,18245$. Sehingga dapat disimpulkan bahwa variabel Simpanan wajib secara parsialtidak berpengaruh signifikan terhadap sisa hasil usaha pada Koperasi Sawit Usaha Manunggal Indragiri Hulu.

\section{PENUTUP}

\section{A. Kesimpulan}

Berdasarkan hasil penelitian mengenai pengaruh variabel Simpanan pokok Dan Simpanan terhadap sisa hasil usaha pada Koperasi Sawit Usaha Manunggal Indragiri Hulu, maka dapat disimpulkan :

1. Hasil dari regresi diperoleh hubungan yang positif antara Simpanan pokok dengan Sisa hasil usaha dan terdapat pula hubungan positif antara simpanan wajib dengan sisa hasil usaha.

2. Dari hasil pengujian hipotesis, dapat diketahui Simpanan pokok dan Simpanan wajib secara bersama-sama bersama-sama tidak berpengaruh secara signifikan terhadap variabel terikat yaitu sisa hasil usaha pada Koperasi Sawit Usaha Manunggal Indragiri Hulu. Sedangkan variabel Simpanan pokok secara parsial tidak berpengaruh signifikan terhadap sisa hasil usaha pada Koperasi Sawit Usaha Manunggal Indragiri Hulu. Dan variabel Simpanan wajib secara parsial tidak berpengaruh signifikan terhadap sisa hasil usaha pada Koperasi Sawit Usaha Manunggal Indragiri Hulu.

3. Hasil koefisien korelasi berganda (R) menunjukkan tingkat hubungan antara seluruh variabel independent terhadap variabel dependent dalam penelitian ini berada dalam kriteria keeratan hubungan sedang atau pengaruh sedang.

\section{B. Saran}

Berdasarkan hasil penelitian yang telah disampaikan di atas, penulis merumuskan beberapa saran yaitu sebagai berikut :

1. Diharapkan Ketua Koperasi Sawit Usaha Manunggal Indragiri Hulu meningkatkan simpanan pokok dan simpanan wajib, sehingga nantinya dapat setara dengan bidang-bidang lainnya yang ada di Koperasi Sawit Usaha Manunggal Indragiri Hulu.

2. Untuk di masa yang akan datang, penulis menyarankan agar peneliti berikutnya dapat meneliti bidang lain yang juga dapat mempengaruhi SHU, sehingga penelitian ini dapat berkembang dan dapat menjadi salah satu sumber bagi pemangku kepentingan dalam membuat sebuah keputusan terkait dengan Koperasi. 


\section{REFERENCE}

Akdon,\& Ridwan. 2010. Rumus dan Data dalam Analisis Statistika Cetakan kedua. Alfabeta.

Andjar Pachta W, dkk. 2005. Manajemen Koperasi : Teori dan Praktek. Graha Ilmu : Yogyakarta.

Arifin Sitio dan Tamba Halomoan. 2001. Koperasi : Teori dan Praktik. Jakarta : Erlangga.

Chariri dan Imam Ghozali. 2000. Teori Akuntansi. Semarang : UNDIP

Ghozali, Imam. 2007. Aplikasi Analisi Multivariate dengan Program SPSS. Badan Penerbit Universitas Diponegoro. Semarang.

Ghozali, Imam. 2009. Aplikasi Analisis Multivariate dengan Program SPSS. Semarang : Badan Penerbit UNDIP.

Kartasapoetra dkk.2001. Koperasi Indonesia yang Berdasarkan Pancasila dan UUD 1945. (edisi revisi). Jakarta : Bumi Aksara.

R. Sutantya Rahardja Hadhikusuma, 2000, Hukum Koperasi Indonesia, Jakarta : PT RajaGrafindo.

Sugiyono. 2009. Metode Penelitian Kuantitatif, Kualitatif dan R\&D. Bandung : Alfabeta.

Swasono. 2005. Indonesia dan Doktrin Kesejahteraan Sosial. Perkumpulan Pra Karsa. Jakarta April 2005. 